\title{
Los Majos, el "españolísimo gremio" del teatro popular dieciochesco: sobre casticismo, inestabilidad y abyección
}

\author{
Rebecca HAIDT \\ Associate Professor of Spanish \\ Department of Spanish and Portuguese \\ Ohio State University \\ Columbus, Ohio 43210, Estados Unidos \\ haidt.1@osu.edu
}

Fecha de recepción: 02/11/2011

Fecha de aceptación: 15/12/2011

\begin{abstract}
RESUMEN
Los majos del teatro dieciochesco popular de Madrid se enorgullecían de su casticismo, o de su genuina "españolidad" (en oposición a "extranjeridad"). Sin embargo, desde el inicio de su formulación literaria, los majos refieren al público de teatro a las luchas subyacentes al cosmopolitismo urbano, tales como la inmigración, la pobreza, el desplazamiento, y lo que Fumerton califica como unsettledness, una condición de inestabilidad que caracterizaba la vida de un sinnúmero de personas en el ámbito urbano capitalino. Paradójicamente, dos características esenciales de su "españolidad" son la marginalización y la inestabilidad de los majos de Madrid. Los majos son a la vez familiares y extranjeros, centrales y periféricos; y a este respecto, haré valer la noción de "lo abyecto" propuesta por Kristeva. Así, los majos configuran una abyección inherente a la construcción cultural de la comunidad "castiza" madrileña en el pasado.
\end{abstract}

Palabras clave: majo, extranjero, barrio, calle, pueblo, cultura, ciudad, memoria, casticismo, pobreza.

\section{Majos, the "españolísimo gremio" of eighteenth-century popular theatre: cas- ticismo, unsettledness and abjection}

\begin{abstract}
The majos of Madrid's eighteenth-century popular theatre were proud of their casticismo, or genuine 'Spanishness' (as opposed to 'foreignness'). However, from their inception in literature, majos refer audiences to the struggles underlying urban cosmopolitanism, such as immigration, poverty, displacement, and what Fumerton terms 'unsettledness', a condition of instability characterizing the lives of countless persons in the capital's urban environment. Paradoxically, two essential characteristics of the 'Spanishness' of Madrid's majos are their marginalization and unsettledness. I draw on Kristeva's notion of 'abjection' to approach some of the ways in which majos are at the same time familiar and foreign/ different, central and marginal, and argue that majos configure an abjection inherent in the cultural construction of 'castizo' community belonging during the past.
\end{abstract}

Key words: majo, foreigner, neighborhood, street, people, culture, city, memory, casticismo, poverty. 
Los majos del teatro dieciochesco popular de Madrid se enorgullecían de su casticismo, o de su genuina "españolidad" (en oposición a "extranjeridad"). Como un personaje en el sainete La crítica, de Ramón de la Cruz lo señalara, los majos eran un "españolísimo gremio"1. Pero antes de comenzar la presente aproximación a esa atribución literaria, he de reconocer que los significados dieciochescos del concepto de "españolidad", como término opuesto a "extranjeridad" o "foraneidad", no son fáciles de definir con precisión. En primer término no se puede negar la dificultad de fundamentar conexiones entre la categoría literaria-cultural "majo" y una población concreta: muchos habrán sido los "majos" entre las variadas poblaciones urbanas del Dieciocho madrileño, pero pocas las fuentes de documentación que proporcionan evidencia en cuanto a sus orígenes y su inserción dentro de marcos de categorización administrativa tales como "extranjero", "natural", o "forastero"2. Igualmente innegable es la convencionalidad de las representaciones de lo "majo" en el género entremesil dieciochesco: los majos del teatro popular son, a fin de cuentas, tipos, productos del proceso mediatizador de la reiteración teatral. Desde luego, hay que tomar en cuenta un tercer factor complicador: la distancia entre cualquier nombre o término categórico -e.g. "extranjero"; "pobre"; "majo"- y su aplicación practicada a las vidas del pasado. Hay que reconocer las divergencias entre, por una parte, las posturas cambiantes de una serie de grupos que entraban y salían, vivían y trabajaban, en los territorios españoles -desde mercaderes extranjeros, artesanos y trabajadores de temporada, hasta grupos de migrantes internos- y, por otra, el lenguaje concretizante, fijante, de las leyes y decretos tocantes en asuntos como residencia, ciudadanía, y lealtad a la Corona ${ }^{3}$.

En el presente ensayo me limito a explorar algunas de las tensiones que subyacen de la designación de los majos como un "españolísimo gremio" en el género entremesil madrileño del siglo XVIII. Centraré la discusión en torno a una cuestión limitada -la de la supuesta "españolidad" de los majos- y consideraré la evidencia disponible en un grupo reducido de textos teatrales -en particular, sainetes y tonadillas ${ }^{4}$. El ensayo se divide en dos partes. En la primera, examino varios aspectos de la construc-

\footnotetext{
${ }^{1}$ Cruz, Ramón de la, La crítica (1770), en Cotarelo y Mori, Emilio (ed.), Sainetes de Don Ramón de la Cruz, Madrid, 1915, 2 vols., vol. 2, pp. 79-86, en p. 82.

2 Sobre estas categorías en los territorios españoles del período, ver: Herzog, Tamar, Defining nations: immigrants and citizens in early modern Spain and Spanish America (New Haven, CT-Londres, 2003), y el ensayo por la misma autora en el presente número monográfico; y Pérez Ledesma, Miguel, «La invención de la ciudadanía moderna», en De la Parra López, Emilio, y otros (eds.), Ciudadanos: El nacimiento de la política en España (18081869), Madrid, 2009, pp. 39-53.

${ }^{3}$ Para estas divergencias y posturas ver, por ejemplo: Crespo Solana, Ana y Montojo Montojo, Vicente, «La Junta de Dependencias de Extranjeros (1714-1800): Trasfondo socio-político de una historia institucional», Hispania, XLIX, 232 (2009), pp. 363-394; y GonzÁlez Beltrán, Jesús Manuel, «Extranjeros en el siglo XVIII: Procesos de integración y de solidaridad interna», en Villar García, Ma Begoña y Pezzi Cristóbal, Pilar (eds.), I Coloquio Internacional "Los extranjeros en la España Moderna”, Málaga, 2003, 2 vols., vol. 1, pp. 379-389.

${ }^{4}$ Sobre el género entremesil madrileño de la época, ver: Álvarez Barrientos, Joaquín, y Lolo, Begoña (eds.), Teatro y música en España: los géneros breves en la segunda mitad del siglo XVIII, Madrid, 2008; Coulon, Mireille, Le sainete à Madrid à l'époque de Don Ramón de la Cruz, Pau, 1993; HaidT, Rebecca, «Plato's Cave and the Stocking-maker's Garret: Shadows of Gender and Genre in eighteenth-century sainetes and tonadillas», Dieciocho, Anejo 4 (Spring 2009), pp. 101-14; Lolo, Begoña, LABrAdor, Germán, y otros (eds.), Paisajes sonoros en el Madrid del S. XVIII: la tonadilla escénica, Madrid, 2003; SAla Valldaura, Josep María, El sainete en la segunda mitad del siglo XVIII. La mueca de Talía, Lleida, 1994; y SubIrÁ, José, La tonadilla escénica, Madrid, 1928-30, 3 vols.
} 
ción del majo como tipo urbano, como son los barrios bajos, la vida en la calle, y la marginación. La segunda parte del ensayo explora la abyección inherente al proyecto de memorialización colectiva que es el casticismo, con referencia a los majos. Planteo el término "majo" como una identidad grupal desarrollada dentro de los contextos de migración interna e integración urbana: el "majo" es un emblema clave para la movilidad característica de la ciudad, donde se mezclaban costumbres y personas locales e importadas, donde la tradición y la innovación se cruzaban constantemente, y los inmigrantes, fueran ricos o pobres, entraban en negociaciones sociales en torno a la identidad como "los de aquí" y "los de fuera". En las representaciones que el género entremesil hacía de una ciudad llena, diversa, repleta de inmigrantes como Madrid, el marco semántico incluía tensiones referentes a la asimilación, la identidad y la ruptura, las cuales se registraban con particular agudeza a través de la integración (al espectáculo teatral) de personajes ("majos" y "majas") que tipificaban una españolidad particularmente urbana elaborada como "lo castizo" (lo que es auténtico, popular o "puro").

Madrid era una ciudad de una variada población flotante de trabajadores migrantes, pobres y no cualificados: como lo apuntara el sainete Las tres graciosas de 1775, invocando a la misma Villa y Corte, "viva la madre, que sustenta extranjeros y naturales"s. El vasto repertorio madrileño de sainetes y tonadillas abunda en imágenes celebratorias del majismo, de las "chuscas" y los majos, del "traje español" y "nacional", del "sal" de los barrios bajos ${ }^{6}$. No obstante, los majos representados en el teatro popular madrileño apuntaban igualmente a lo que Leandro Fernández de Moratín, en 1792, denominó "El populacho más infeliz": inmigrantes, transeúntes,

\footnotetext{
5 Anónimo, Las tres graciosas, Biblioteca Histórica Municipal de Madrid (en adelante BHMM), Mss. Mus 6427: cit. en NúÑ̃z, Faustino, Guía comentada de música y baile preflamencos (1750-1808), Barcelona, 2008 , p. 72. Sobre la importancia de la inmigración y los flujos de poblaciones en la formación de la capital durante la época, ver: Bravo Lozano, Jesús, «La emigración a Madrid», en Santos Madrazo y Pinto Crespo, Virgilio (eds.), Madrid en la época moderna: espacio, sociedad y cultura, Madrid, 1991, pp. 131-58; CARBAJo Isla, María F., La población de la villa de Madrid desde finales del siglo XVI hasta mediados del siglo XIX, Madrid, 1987; Gómez Porro, Francisco, La conquista de Madrid: paletos, provincianos e inmigrantes, Madrid, 2000; JimÉnEz MANCHA, Juan, Asturianos en Madrid: Los oficios de las clases populares (siglos XVI-XX), Gijón, 2007; Julí́, Santos, Ringrose, David, y otros (eds.), Madrid: Historia de una capital, Madrid, 2005; López García, José Miguel, «El henchimiento de Madrid. La capital de la monarquía hispánica en los siglos XVII y XVIII», en Capitales y corte en la historia de España, Valladolid, 2003, pp. 45-104; MARCos MARTín, Alberto, «Movimientos migratorios y tendencias demográficas en Castilla la Vieja y León a lo largo de la época moderna», en Eiras Roel, Antonio y Rey Castelao, Ofelia (eds.), Migraciones internas y medium-distance en la península Ibérica, 1500-1900, Santiago de Compostela, 1994 , vol. 2, pp. 209-45; y Ringrose, David, «Inmigración, estructuras demográficas y tendencias económicas en Madrid a comienzos de la época moderna», Moneda y Crédito, 138 (Septiembre 1976), pp. 9-55.

${ }^{6}$ Ofrezco una discusión extendida del "sal" de los barrios bajos, en HaIDT, Rebecca, Women, work and clothing in eighteenth-century Spain, SVEC, Oxford, 2011, caps. 6 y 7. Sobre los majos, ver también: CARo Baroja, Julio, «Los majos», en Temas castizos, Madrid, 1980, pp. 15-101; Coulon: op. cit. (nota 4); GonzÁlez Troyano, Alberto, «La figura teatral del majo: conjeturas y aproximaciones», en SALA VALLDAURA, Josep María (ed.), El teatro español del siglo XVIII, Lleida, 1996, vol. 1, pp. 475-86; HuERTAS VÁsquez, Eduardo, «Los majos madrileños y sus barrios en el teatro popular», en Huerta Calvo, Javier y Palacios Fernández, Emilio (eds.), Al márgen de la Ilustración: cultura popular, arte y literatura en la España del siglo XVIII, Amsterdam-Atlanta, 1998, pp. 118-143, y «El singular escenario del barrio de la comadre», en Sala Valldaura: op. cit. (en esta nota), vol. 2, pp. 525-48; López García, José Miguel, El Motín contra Esquilache. Crisis y protesta popular en el Madrid del siglo XVIII, Madrid, 2006; y Sala Valldaura, Josep María, Los sainetes de González del Castillo en el Cádiz de finales del siglo XVIII, Cádiz, 1996, y Sala Valldaura: op. cit. (nota 4).
} 
rateros, marginados, "en suma, las heces asquerosas de los arrabales de Madrid"7. (De hecho, en 1734, el Diccionario de Autoridades definió a los majos como "los que viven en los arrabales de esta corte"). Félix María de Samaniego comentó en 1786 lo imbricado que estaban los majos en las obras teatrales que tomaban como asunto al pueblo bajo: "las naranjeras, rabaneras, vendedoras de frutas, flores y pescado, dieron origen a estos pequeños melodramas; entraron después en ellos los cortejos, los abates, los militares y las alcahuetas; pero los majos faltan rarísima vez en estas composiciones"8. Así, desde el inicio de su formulación literaria como grupo emblemático de la "españolidad", los majos refieren al público de teatro a las luchas subyacentes al cosmopolitismo urbano, tales como la inmigración, la pobreza, el desplazamiento, y lo que Fumerton califica como unsettledness, una condición de inestabilidad que caracterizaba la vida de un sinnúmero de personas en el ámbito urbano capitalino9 . Según Fumerton, el uso del concepto unsettledness (inestabilidad) permite evitar una atribución de vagabundaje, mendicidad o maldad a los miles de pobres -migrantes, jornaleros, gente sin calificaciones, sin domicilio fijo- que trabajaban fuera de marcos oficiales de empleo, y cuyas vidas se encontraban "en un estado de ruptura" ${ }^{10}$. Paradójicamente, dos características esenciales de su tipología son la marginalización y la inestabilidad de estos majos "españolísimos" 11 .

Así, el término "majo" también connota el debilitamiento o desestabilización de la "españolidad", en el sentido de que tal identidad inestable -"el majo"- es producto del flujo y de una condición sospechosa. Un aspecto importante de la imagen teatral del "españolísimo gremio" es su representación como españoles de mal vivir, con propensidad a hurtar y crear disturbios, semejante a la atribuida a grupos más claramente tachados de extranjería como eran los gitanos ${ }^{12}$. Los majos del género entremesil son a la vez familiares y extranjeros, centrales y marginados; $\mathrm{y}$ a este respecto, haré valer la noción de "lo abyecto" propuesta por Julia Kristeva: lo abyecto es lo marginado por el impulso sistematizador, cuya función depende de la purificación frente al "horror" de lo heterogéneo que debiera ser excluido ${ }^{13}$. Lo que Gómez Porro comenta sobre los campesinos que migraban a áreas urbanas tiene también aplicación para las representaciones de la abyección de los majos: esto es, los majos nos refieren al hecho de que miles de miembros de la población inestable (o unsettled) estaban "privados de existencia cívica en el Madrid imperial que en 1561 se convertía en capital de España y corte de un inmenso imperio" y "convertidos en el hazmerreír o en chivos expiatorios de funcionarios en el sainete madrileñista, confinados en el apunte

7 Cit. en Huerta Calvo, Javier, «Comicidad y marginalidad en el sainete dieciochesco», Scriptura, 15 (1995), pp. $51-75$, p. 52 .

${ }^{8}$ Cit. por Subirá: op. cit. (nota 4), vol. 1, pp. 34-35.

9 El término unsettled desarrollado por Fumerton es difícil de traducir directamente al español: el concepto conlleva connotaciones no solo de "inestable", sino también de "sin destino comodo", "sin asentamiento", "sin domicilio fijo". Ver: Fumerton, Patricia, Unsettled: The culture of mobility and the working poor in early modern England, Chicago, IL-Londres, 2006, caps. 1 y 2.

${ }_{10}$ Ibidem, 17.

11 Me centro aquí en representaciones teatrales de los majos en Madrid. Para discusiones sobre el majismo teatralizado en otras ciudades (e.g. Cádiz), ver, por ejemplo, SAla VAlldaura: op. cit. (nota 6, 1996).

12 Sobre la "extranjería" de los gitanos, ver el ensayo de Herzog en el presente monográfico.

13 Kristeva, Julia, Powers of horror, Nueva York, 1982, p. 210. 
costumbrista, en el artículo periodístico o en la balumba del género ínfimo" ${ }^{14}$. Exclusión, conversión en asunto costumbrista, transmogrificación en sustancia elemental de "lo popular" -éstas hacen constar la abyección que subyace en la "pureza" del casticismo y la "españolidad" de los personajes majos. Los textos del teatro popular tales como sainetes y tonadillas sugieren que los majos, el "españolísimo gremio", son más españoles -esto es, más representativos de los trabajadores, migrantes, pobres, y personas indocumentadas que formaban la mayoría de la población urbana- en la medida en que tienen menor acceso a los privilegios acordados a los poseedores de buen nombre, propiedad, y beneficios. En este respecto los majos son, para emplear de nuevo el lenguaje de Gómez Porro, una "tropa sin historia y sin memoria que ha hecho a Madrid" (11), cuyas experiencias diversas en la capital se forjaban por el deseo español compartido de "ser alguien" (11). Los majos son el índice de una doble ausencia acondicionadora de la memoria colectiva, determinada por la escasez de documentación de las experiencias del "españolísimo gremio" de álguienes en el Madrid dieciochesco, y la construcción, por medio de un casticismo celebratorio, de una aporía cultural en torno a la abyección del pueblo bajo heterogéneo.

\section{ESPAÑOLIDAD E INESTABILIDAD EN EL ÁMBITO URBANO: PAISA- NAJE, CALLE, BARRIO, PERIFERIA}

Los majos están particularmente vinculados a la experiencia urbana, más que a la rural. Caro Baroja sugiere que la diferencia entre el payo, quien "llega a la corte o a la capital de provincia y para él todo son maravillas", y el majo, es que el majo es "en esencia ciudadano, o de zona suburbana" ${ }^{15}$. Esto significa que los majos descienden de, o son ellos mismos, personas que han migrado a la ciudad (ya sea recientemente o hace tiempo); y un aspecto crucial de la tipología del majo es su performance activo de una identidad de pertenencia urbana. Los majos y su tipo cercano, los manolos, representan trabajadores que descienden, o fueron ellos mismos, inmigrantes de pueblos en las áreas rurales alrededor de Madrid, y de ciudades en otras regiones de la Península (ya sea la región sur, este o central): a diferencia de los payos (afirma Caro Baroja), los majos son producto de sucesivas olas de inmigración desde los remotos "barrios populares" (asentamientos populares o de la clase trabajadora) (66). El teatro popular distingue claramente entre los tipos representacionales que la escenografía debía sustentar y que los actores que hacían los papeles respectivos de majos y payos debían asumir. Por ejemplo, en La pradera de San Isidro de Cruz, el dramaturgo inserta exhaustivas instrucciones con respecto a un cuadro teatral que debe incluir payos merendando en familia, y majos bailando aparte de los payos ${ }^{16}$.

\footnotetext{
14 Gómez Porro: op. cit. (nota 5), p. 11.

15 Caro Baroja: op. cit. (nota 6), p. 24. Sobre los payos en la literatura, ver también: Gómez Porro: op. cit. (nota 5) y Sala Valldaura, Josep María, «El payo y la ciudad en los sainetes de Ramón de la Cruz y González del Castillo», Cuadernos de Ilustración y Romanticismo, 3 (1994), pp. 115-133.

${ }^{16}$ Cruz, La Pradera de San Isidro (1766), en Cotarelo y Mori: op. cit. (nota 1), vol. 1, pp. 311-19, p. 313.
} 
De acuerdo con Caro Baroja, el origen de los majos debería estar en los trabajadores cualificados y no cualificados, quizás de ascendencia morisca, quienes emigraron de Andalucía hacia la recién establecida corte entre mediados y finales del siglo XVI. "Lo majo madrileño nos obliga a mirar siempre, hacia Mediodía", afirma Caro; "el eje Madrid-Sevilla es fundamental para comprender la vida popular española en rasgos esenciales" (77). La especulación de Caro parece hacer eco a las representaciones exhibidas en las obras del género entremesil del siglo XVIII. Por ejemplo, en el sainete El agente de sus negocios, de Cruz, cuando se le señala a un "majo ocioso" que la mujer que quiere casarse con él es una "mujer baja" (48), él pregunta retóricamente: "Pues, ¿acaso mi familia/ desciende de La Giralda?" ". El majo sitúa su linaje en el sur de España, al tiempo que señala la ironía de que alguien supusiera que los majos descendían de la élite hispano-árabe. Y en La víspera de San Pedro, también de Cruz, tres mujeres (claramente vestidas como "majas", de acuerdo a las acotaciones de escena) se refieren a sí mismas como venidas de Andalucía. El diálogo especifica que los actores deben utilizar el acento marcado y la pronunciación propia del sur: "Despacio, seora Andaluza, que ahora hablaré" dice una de las majas a otra ${ }^{18}$.

Sin embargo, los majos del género entremesil madrileño no eran solamente de origen sureño. Son, en cambio, figuras que capturan la experiencia más amplia del inmigrante, la cual da forma a gran parte de la población de la capital. Una de las más destacadas características de los majos es que provienen de "la base de una población de aluvión muy característica", según Huertas; "esta población fue llegando a Madrid desde diversas provincias y ciudades de las Españas y, en sucesivas oleadas, se fue posando sobre el substrato originario de la población madrileña" ${ }^{19}$. Mesonero Romanos apunta a sus lectores hacia la diversidad, causada por variadas migraciones pan-peninsulares, de los barrios pobres o de clase trabajadora de Madrid, cuyos residentes, majos y manolos, venían desde tiempo atrás de regiones tan diversas como Galicia, Toledo y Valencia ${ }^{20}$. De acuerdo con Mesonero, "majos" y "manolos" indican una identidad grupal formada a lo largo de siglos de integración urbana "con la población propia de nuestra villa y la agregación de los infinitos advenedizos que de todos los puntos del reino acudieron a ella desde el principio, a buscar fortuna" (188). Mesonero explícitamente menciona los orígenes inmigrantes de los majos madrileños, quienes descienden de los "habitadores de Triana, Macarena y el Compás, de Sevilla, los de las Huertas de Murcia y de Valencia, de la Mantería de Valladolid, de los Percheles y las islas de Riarán de Málaga, del Azoguejo de Segovia, de la Olivera de Valencia, de las Tendillas de Granada... y demás sitios célebres del mapa picaresco de España" (188-189) ${ }^{21}$.

\footnotetext{
17 Una referencia al monumento de la cultura hispano-árabe más arquetípico de la península: Cruz, El agente de sus negocios (1762), en COTARElo y Mori: op. cit. (nota 1), vol. 1, pp. 46-50.

18 Cruz, La víspera de San Pedro (1763), en Cotarelo y Mori: op. cit. (nota 1), vol. 1, pp. 125-30, p. 125.

19 Huertas Vásquez: op. cit. (nota 6), p. 133.

${ }^{20}$ Mesonero Romanos, Ramón, El antiguo Madrid, Madrid, 1861, pp. 188-89.

${ }^{21}$ Mesonero escribe El antiguo Madrid durante un período de fuerte crecimiento en el número de inmigrantes pobres y trabajadores a Madrid. Sobre la inmigración pan-peninsular a la capital hacia mediados del siglo XIX, ver: Carballo, Borja, Pallol Trigueros, Rubén, y otros, El Ensanche de Madrid: Historia de una capital, Madrid, 2008; y Juliá: op. cit. (nota 5).
} 
Una de las características esenciales de cualquier ciudad era su permeabilidad a poblaciones transeúntes y migrantes; tal población flotante fue uno de los principales factores que condicionaron la vida en el Madrid del siglo XVIII ${ }^{22}$. El influjo de inmigrantes oriundos del centro de la Península, por ejemplo, queda capturado en una canción incluida en Las majas vengativas, de Cruz: "Es la corte la mapa/de ambas castillas, /y la flor de la corte/las Maravillas" ${ }^{23}$. En los sainetes de Cruz, los personajes majos hacen múltiples referencias a sus orígenes fuera de la capital. En El careo de los majos, un majo se identifica a sí mismo como "Lionisio el de Arganda", y una maja como "Juliana de Fuencarral"; mientras que una maja viuda, muy querida en el barrio, es de La Mancha ${ }^{24}$. ("Es el caso", según la tonadilla A cantar va Joaquina, de Palomino, que "en la Mancha... todos los majos" cantan juntos el elogio a ciertos otros majos) ${ }^{25}$. Un majo en El agente de sus negocios, de Cruz, alude al hecho de que él es de una familia inmigrante del sur; y La víspera de San Pedro, también de Cruz, presenta algunas majas de Sevilla y otras partes de Andalucía ${ }^{26}$. Puede haber "majos del lugar", como es el caso del sainete Las frioleras, de Cruz, en el cual una maja es tabernera en un pueblo ubicado a las afueras de la capital; o de La junta de los payos, también de Cruz, en el que se pide la entrada de "los majitos del lugar" 27 . La tonadilla La provisión de Madrid, de Esteve, identifica a la capital como una ciudad abastecida por la inmigración tanto de lugares próximos como de regiones lejanas: Alcarria, Asturias, Murcia, Valencia ${ }^{28}$. Con frecuencia hay referencias a la "foraneidad" de varias personas dentro de los espacios urbanos asociados con los majos. En algunos sainetes, "forastero" es un término usado por personajes majos para denotar recién llegados al barrio o transeúntes. Por ejemplo, dos majas andaluzas en Las calceteras, de Cruz, son vistas como "unas damas forasteras"; y en Los majos de buen humor, también de Cruz, se describe a dos majas andaluzas como "forasteras" que "no conocen un alma" 29 . Los majos vencidos de Cruz presenta a una maja que se describe a sí misma como una "forasterita" ${ }^{30}$. Los majos pueden parecer vagantes, como (por ejemplo) en el sainete manuscrito La expulsión de las majas de Madrid (percepción bien comprensible de acuerdo con el concepto de "inestabilidad" desarrollado por

${ }^{22}$ Nieto SÁnchez, José A., Artesanos y mercaderes. Una historia social y económica de Madrid (1450-1850), Madrid, 2006, p. 157. Sobre la permeabilidad como característica de la ciudad, ver, por ejemplo: MorÁn, María Luz, «Espacios y ciudadanos: los lugares de la narración clásica de la ciudadanía», Reis, 119 (Jul.-Sep. 2007), pp. 11-34; Nicholas, David, Urban Europe 1100-1700, Basingstoke, 2003; y PALlol Trigueros, Rubén, «Ciudad e identidad en el siglo XIX-El proceso de urbanización como proceso de fondo en la creación de nuevas identidades: Jornaleros e inmigrantes en el Ensanche norte de Madrid», www.ahistcon.org/docs/Santiago/pdfs/s4y.pdf [Consulta: 1 nov. 2011 ]

${ }^{23}$ Cruz, Las majas vengativas (1768), en COTARElo y MorI: op. cit. (nota 1), vol. 1, pp. 454-59, p. 456. Maravillas (ahora Malasaña) era uno de los barrios bajos más frecuentemente asociados con las poblaciones heterogéneas e inestables.

${ }^{24}$ Cruz, El careo de los majos (1766), en Ibidem, vol. 1, pp. 277-83, p. 280 y 282.

25 Palomino, José, A cantar va Joaquina, BHMM, Mss. Mus 74-7, cit. en NúÑEZ: op. cit. (nota 5), p. 75.

${ }_{26}$ Cruz, El agente de sus negocios (1762), en Cotarelo y Mori: op. cit. (nota 1), vol. 1, pp. 46-50, p. 48, y La vispera de San Pedro (1763), en Ibidem, vol. 1, pp. 125-30.

${ }^{27}$ CRuz, Las frioleras (1764), en Ibidem, vol. 1, pp. 155-161, p. 158, y La junta de los payos (1761), en Ibidem, vol. 1 , pp. $18-22$, p. 20.

${ }^{28}$ Esteve, Pablo, La provisión de Madrid, BHMM, Mss. tea 223-45.

${ }^{29}$ CRuz, Las calceteras (1774), en Cotarelo y Mori: op. cit. (nota 1), vol. 2, pp. 409-16, p. 410, y Los majos de buen humor (1770), en Ibidem, vol. 2, pp. 111-17, p. 113.

${ }^{30}$ CRUz, Los majos vencidos (1771) en Ibidem, vol. 2, pp. 172-77. 
Fumerton); "vagancia" era la categoría dentro de la cual los registros legales y administrativos colocaban a las poblaciones e individuos considerados peligrosos porque no tenían domicilio fijo y lealtad local, y este sainete ofrece una enumeración variopinta de personajes sospechosos, vigilados, o perseguidos por las autoridades ${ }^{31}$.

Desde luego, con frecuencia los majos teatrales citan sus orígenes en las zonas más pobres de la capital misma. Un majo en El hospital de la moda, de Cruz, declara "soy del Barquillo"; y en La hostería de buen gusto, también de Cruz, la esposa maja de un tabernero francés proclama sus orígenes madrileños: "me llamo Catalina/Leonarda de San Tadeo,/nacida y criada en la/misma calle de San Pedro/la baja" 32 . No obstante, esta misma Catalina Leonarda de San Tadeo percibe a sus amigos "majos" como paisanos de la Villa y Corte: cuando su esposo francés declara que toda la comida y bebida en la taberna debe ser dedicada a las festividades para sus amigos franceses, la maja declara "ni tampoco a mis paisanos/los he de dejar yo hambrientos" (354). El "paisanaje", según Recio, es un término usado para referir a una "identidad común compartida basada en el origen" tal como en el sentido de fellow countrymen, y se puede usar, igual como la categoría conceptual "nación", para expresar un sentido de identidad común entre "paisanos" 33 . La maja de La hostería de buen gusto se identifica con "paisanos" -majos- que refieren al auditorio a personas actuales cuyas vidas se acondicionaban por la dificultad de encontrar trabajo y sustento en el ámbito de la corte. La mayoría de los trabajadores que llegaban a Madrid tenían que enfrentarse con las limitaciones y restricciones de contratación, trabajo, producción y distribución impuestas por los gremios y el Ayuntamiento. Solo una pequeña minoría era capaz de alcanzar maestría (alcanzar el estatus de maestro) o de encontrar trabajo con maestros pertenecientes a los gremios; las oportunidades contingentes y temporales de trabajo (tales como las asociadas a la construcción) garantizaban que algunos trabajadores no cualificados o poco cualificados fueran capaces de arañar lo necesario para la subsistencia en sectores periféricos ${ }^{34}$. Aquellos que habían estado en la capital por más tiempo podían ayudar a los paisanos recién llegados en su búsqueda de empleo en sectores que empleaban trabajo no cualificado o sin licencia. Por ejemplo, en Madrid, muchos inmigrantes de Galicia se convirtieron en cargadores de agua; numerosos llegados de Valencia vendían refrescos en las calles; generaciones de hombres de regiones del norte eran transportistas y carreteros. Sola-Corbacho hace eco a la afirmación de Domínguez Ortiz de que la solidaridad de grupo y el paisanaje son cruciales para entender cómo los españoles del siglo XVIII se veían a sí mismos en el mundo ${ }^{35}$. Al venir al crisol que es Madrid, personas como los majos son

\footnotetext{
${ }^{31}$ Anónimo [Morales?], La expulsión de las majas de Madrid, Biblioteca Nacional de Madrid (en adelante BNM), Mss. 14596/6. Sobre la vagancia, ver: Pérez Estévez, Rosa María, El problema de los vagos en la España del siglo XVIII, Madrid, 1976; y Ramos VÁsqueZ, Isabel, «Policía de vagos para las ciudades españolas del siglo XVIII», Revista de Estudios Histórico-Jurídicos, XXXI (2009), pp. 217-58.

${ }^{32}$ Cruz, El hospital de la moda (1762), en Cotarelo y Mori: op. cit. (nota 1), vol. 1, pp. 51-56, p. 55, y La hostería de buen gusto (1773), en Ibidem, vol. 2, pp. 354-360, p. 355.

${ }^{33}$ Recio Morales, Óscar, «Irish émigré group strategies of survival, adaptation and integration in seventeenthand eighteenth-century Spain», en O'Connor, Thomas y Lyons, Mary Ann (eds.), Irish Communities in EarlyModern Europe, Dublín, Four Courts Press, 2006, pp 240-266.

${ }^{34}$ NiETO: op. cit. (nota 22).

35 Sola-Corbacho, Juan Carlos, «Family, paisanaje, and migration among Madrid's merchants (1750-1800)»,
} 
representadas (en el teatro popular) como forjadores de algo mayor que la suma de sus partes: un paisanaje de aquellos que comparten la membresía en el "españolísimo gremio", una identidad vecinal fundamental en la integración urbana y la pertenencia a un barrio ${ }^{36}$. Nos enfrentamos a un término, "majo", que refiere a los espectadores a un conjunto de conceptos entrelazados ("vecino", "forastero", "español", "paisano") a través de los cuales los autores figuraban las complejidades del espacio urbano del siglo XVIII.

Una de las claves de la pertenencia a la comunidad cívica en el Madrid del siglo XVIII era la cuestión de "vecindad", o posesión del estatus de vecino. Un "vecino" podía ser (de acuerdo con el Diccionario de Autoridades) "[el que] habita con otros en un mismo barrio, casa, u pueblo", pero también significaba "el que tiene casa, y hogar en un pueblo, y contribuye en el en las cargas, u repartimientos, aunque actualmente no viva en el"; más adelante, significó "[el que] ha ganado domicilio en un pueblo, por haber habitado en el tiempo determinado por la ley". Un "extranjero", según el Diccionario de Autoridades, es "[el] que no es de aquella tierra donde vive". En el siglo XVIII (apunta Herzog) muchos "extranjeros" podían aspirar al estatus de vecinos y gozar de "un amplio rango de beneficios fiscales, económicos, políticos, sociales y simbólicos en retorno por el cumplimiento de ciertos deberes" ${ }^{37}$.

Ahora bien, la España del siglo XVIII se componía de muchas comunidades, y era un "territorio de acogida de inmigrantes procedentes de diversos orígenes europeos" 38 . La creación de cuerpos como la Junta de Dependencias de Extranjeros está relacionada con la vigencia, de parte de la Corona, por los intereses comerciales españoles y su entretejido con las complejas cuestiones de privilegios, comunidades, corporaciones, derechos, y censos que surgían con referencia a las diferentes naciones ${ }^{39}$. Sin embargo, los majos madrileños, aún cuando tuvieran sus raíces en las olas de inmigración a la Villa y Corte, no pertenecían a las poblaciones de "extranjeros" vigiladas por cuerpos como la Junta de Dependencias de Extranjeros. Ni se llegarían a contarse entre los números de "vecinos" oficialmente censados como gozadores de privilegios y beneficios, ya que un buen porcentaje de las poblaciones inestables no queda documentado por instrumentos como padrones, censos, registros matrimoniales, etc. Estos grupos eran, efectivamente, excluidos de ese "amplio rango de beneficios" otorgados a aquellas personas, extranjeros y vecinos, afiliados con el estado, los gremios, el comercio, o los intereses municipales. Muchas personas referidas por el término "majos" hacían los trabajos de subsistencia, contingentes y mal pagados, que estaban disponibles para las poblaciones inestables dentro y en los alrededores de la capital, y gozaban de manera correspondiente no de privilegios fiscales y propiedad, sino marginación.

En sainetes y tonadillas, los majos se definen a sí mismos como gente sin privilegios cuyo trabajo los distingue de aquellos -fueran extranjeros de nacionalidad no es-

Journal of Family History, 27.1 (January 2002), pp. 3-24, p. 4; cit. a Dominguez Ortiz, Antonio, Sociedad y Estado en el siglo XVIII español, Barcelona, 1976, p. 327.

36 Ver también Herzog: op. cit. (nota 2).

37 Ibidem, p. 6.

${ }^{38}$ CRespo Solana: op. cit. (nota 3), p. 365.

${ }^{39}$ Ibidem, pp. 374-75. 
pañola, o extranjeros de otras partes del territorio español- que vienen a la ciudad por negocios relacionados con la corte o el comercio; tales personas reciben el nombre de "usías" en las obras del género entremesi1 ${ }^{40}$. El sainete El deseo de seguidillas, de Cruz, explícitamente presenta a los majos como tal "pueblo de menestrales":

\author{
Solo sé que cuando voy \\ A los arrabales nuestros \\ Veo bayeta y rodetes \\ Paño pardo con remiendos \\ Mujeres que laven, críen \\ Y cuiden de su puchero; \\ Hombres que vengan cansados \\ Del trabajo, y hablen recio, \\ Y que de cada suspiro \\ Echan una casa al suelo ${ }^{41}$.
}

Desde la inclusión de detalles concernientes a los tipos de textiles que los trabajadores pueden costear (bayeta, paño pardo), al hecho de que la mayoría de la gente pobre tenía que remendar y poner parches a su ropa para hacerla durar más ("paño pardo con remiendos"), y en la mención explícita del trabajo físicamente agotador que las poblaciones inestables tenían que desempeñar ("hombres que vengan cansados del trabajo, y hablen recio"), el texto de Cruz expone la vida diaria de una amplia gama de trabajadores y pobres habitantes de los barrios marginados ("los arrabales nuestros") y los emblematiza a través de la figura del majo. En los distritos de la periferia de la ciudad (orgullosamente apunta el hablante en El deseo de seguidillas) vive la laboriosa gente castiza de Madrid, aun cuando a sus niños les falte ropa ("aquellos chicos en cueros", p. 23), y sus hombres luzcan despeinados y sin afeitar ("aquellos/ hombres tan mal afeitados", p. 23). En el detalle de "los arrabales nuestros", Cruz contundentemente refiere la situación miserable de la mayoría de la población inestable que alimentaba las industrias de la ciudad, al tiempo que evoca la insistencia de los majos en el valor de los privilegios comunitarios entre las personas "castizas".

En la Europa de la modernidad temprana, los pobres y los trabajadores temporales o no cualificados eran frecuentemente interrogados o detenidos por las autoridades urbanas por no exhibir el atuendo propio u otros signos visibles de ocupaciones aprobadas oficialmente ${ }^{42}$. En este contexto, "lo castizo" es inseparable de los sistemas económicos de la capital, ya que los trabajos realizados por legiones de trabajadores sin privilegios eran todo menos marginales, o sea, eran esenciales a la función diaria y la expansión de la ciudad. "Lo castizo" es igualmente inseparable de la creciente presión que había sobre inmigrantes y transeúntes para definirse a sí mismos

\footnotetext{
${ }^{40}$ Sobre los "usías" en el teatro popular, ver: Coulon: op. cit. (nota 4); y HaIDT: op. cit. (nota 6).

${ }^{41}$ Cruz, El deseo de seguidillas (1769), en Cotarelo y Mori: op. cit. (nota 1), vol. 2, pp. 22-27.

42 Ver Fumerton: op. cit. (nota 9); JütTe, Robert, Poverty and Deviance in Early Modern Europe, Nueva YorkCambridge, 1994; López Barahona, Victoria, El cepo y el torno. La reclusión femenina en el Madrid del siglo XVIII, Madrid, 2009; López García: op. cit. (nota 6); Pérez Estévez: op. cit. (nota 31); y Pike, Ruth, Penal Servitude in Early Modern Spain, Madison, 1983.
} 
como reclamantes abiertos de una identidad española y como visibles participantes en comunidades locales. Pérez-Bustamante Mourier ofrece varios significados que resuenan en el casticismo encarnado por personajes teatrales que se llaman "majos", entre ellos: costumbres o discursos locales (en vez de importados); la exhibición de cualidades típicas de una región en particular (e.g. un "auténtico" madrileño, aragonés, etc.); lealtad y honestidad; y pureza ${ }^{43}$. Sin embargo, frente a los controles corporativos y las exclusiones, y frente a las sospechas que el gobierno municipal tenía sobre aquellos que no estaban bajo la protección de un gremio o no eran fácilmente identificables como "vecinos" de acuerdo con las normas del gremio, la comunidad y la ley, la importancia de "lo castizo" en sainetes y tonadillas sobre majos indica la necesidad de adjuntar otros significados a la lista. La insistencia de los majos teatralizados en ser el "pueblo castizo" de Madrid refiere al espectador a algo crucial que era -para estos menestrales, jornaleros y personas inestables- necesario para sobrevivir en el Madrid de finales del siglo XVIII: la identificación con una comunidad local y la capacidad de reclamar los derechos y reputación propios de la pertenencia a una comunidad de "álguienes".

Comentando sobre la importancia de la vida en las calles para los procesos de integración urbana, Morán anota que "la confianza que se genera en la calle es un elemento esencial para la creación de identidades ciudadanas sólidas", la cual surge del hecho de que las calles facilitan contactos entre "los vecinos y, sobre todo, con los extraños", de manera que "sin calle... no puede haber ciudadanía activa" Los procesos de integración al nivel de las calles toman lugar dentro del marco más amplio de la formación de comunidad en el barrio, tal como lo señala Huertas: "el barrio [deviene] en una entidad natural de gran intensidad social, y constituye, al mismo tiempo, el medio ambiente, más cercano, más concreto y diferenciado del individuo en la sociedad urbanizada" 45 . En efecto, "la conciencia de ser de un barrio ofrece siempre, dentro de la dispersa globalidad de la gran metrópoli, la posibilidad de que el vecino no pierda el nexo y renueve siempre el contacto con su más concreta dimensión" ${ }^{46}$. La solidaridad y el apoyo mutuo eran prácticas sociales muy comunes entre los paisanos que llegaron a barrios, lo cual era importante para que los recién llegados pudieran integrarse dentro de las sociedades urbanas. Esto implicaba que los miembros de las comunidades siempre trataban de vivir tan cerca como pudieran, lo cual significaba que las ciudades usualmente se dividían en barrios definidos por el origen geográfico de sus residentes ${ }^{47}$. La importancia de los barrios en la vida urbana del siglo XVIII indica el papel central de los lazos de paisanaje en las ciudades con alta inmigración (tales como Madrid) ${ }^{48}$. Existía entonces una fuerte "conciencia de

\footnotetext{
43 Pérez-Bustamante Mourier, Ana-Sofía, «Cultura popular, cultura intelectual y casticismo», en PérezBustamante, Ana-Sofía, Romero Ferrer, Alberto, y otros (eds.), Casticismo y literatura en España, Cádiz, 1992 , pp. 125-162, pp. 126-27. Ver también: RoMERo FERRER, Alberto, «Pervivencia y recursos del casticismo en la dramaturgía corta finisecular: El Género Chico», en Ibidem, pp. 61-95.

${ }^{44}$ MorÁn: op. cit. (nota 22), p. 22.

45 Huertas VÁsquez: op. cit. (nota 6), p. 118.

46 Ibidem, p. 118.

47 Sola-Corbacho: op. cit. (nota 35), p. 5.

48 Ibidem, p. 5.
} 
identidad regional" en algunos de los barrios bajos de la capital, y los orígenes compartidos ayudaban a afianzar la nueva formación de comunidad que los trabajadores estaban forzados a emprender en una gran ciudad como Madrid $^{49}$. La calle y el barrio vienen a ser componentes esenciales de la españolidad en la Villa y Corte.

El reclamo de vida y residencia en calles y lugares públicos es fundamental dentro del casticismo teatralizado. De hecho, los "barrios bajos" tenían un significado teatral que denotaba la acción que ocurría en las calles ${ }^{50}$. En los textos del teatro popular, los majos son ubicados en lugares públicos urbanos tales como calles y barrios, en los cuales la movilidad y los flujos sociales propios de la vida urbana proporcionaban las mayores oportunidades para poblaciones marginadas y gente "inestable". Por ejemplo, en La maja majada de Cruz, la acción toma lugar en "La calle de la Paloma"51. En las acotaciones de escena de Los majos vencidos, también de Cruz, se pide que la escenografía represente "la calle pública" (p. 172). Las acotaciones escénicas de Las calceteras, de Cruz, estipulan que la escena debe representar "una calle pública de Madrid" (p. 409); y en El refunfuñador, también de Cruz, una maja vendedora de flores dice "hablaré/cuanto quiera, que es muy mía/la calle" 52 . La maja, forzada por sus clientes a entrar a sus casas a vender su mercancía, se queja de que ellos no bajen a la calle -su calle ("muy mía")- a hacer las compras (p. 120). Los majos imaginados por Cruz expresan orgullo de vivir en las calles y los barrios de la clase trabajadora: "La calle de San Pedro" (La hostería de buen gusto); "La calle de la Paloma" (La maja majada); "Barquillo" (El Hospital de la moda); "la calle muy mía" (El refunfuñador). La asociación esencial entre majos y los espacios de las calles es claramente evidente en el sainete Manolo, de Cruz, en el cual el gracioso Chinica, quien ha escrito una tragedia, explica que ha ubicado la acción no en Grecia ni en Roma, sino en Madrid; y no solo en Madrid, sino en las calles de la capital, "en medio de la calle", "en Lavapiés" 53 . En esta parodia de las convenciones de la tragedia, las locaciones normalmente presentadas dentro del género teatral de la tragedia -palacios, campos de batalla, sitios de poder legitimado- se convierten en espacios donde las poblaciones marginadas se concentran (siendo "Lavapiés" y "en medio de las calles" el grado cero de tales elementos urbanos en el contexto sainetesco madrileño).

La literatura dramática popular de Madrid refleja las luchas en torno a la formación de comunidad en los barrios y calles de la ciudad. (En efecto, el sainete de Cruz La crítica -en el cual los majos son designados como "el españolísimo gremio"- fue originalmente titulado Los cuatro barrios) ${ }^{54}$. La práctica de "ser alguien" dentro del barrio viene a ser punto clave del majismo, y necesidad para sobrevivir al desafío de la heterogeneidad ${ }^{55}$. Por ejemplo, en Los majos vencidos, de Cruz, un grupo de hombres vestidos como majos entra a una boda; dándose cuenta de aquello un majo

${ }^{49}$ Huertas VÁsquez: op. cit. (nota 6), p. 119.

50 Espín Templado, Pilar, «El casticismo del género chico», en Pérez-Bustamante: op. cit. (nota 43), pp. 25-58.

${ }^{51}$ Cruz, La maja majada (1774), en Cotarelo y Mori: op. cit. (nota 1), vol. 2, pp. 428-34, p. 428.

${ }_{52}$ Cruz, El refunfuñador (1763), en Ibidem, vol. 1, pp. 118-24, p. 124.

${ }^{53}$ Cruz, Manolo (primera parte) (1769), en Ibidem, vol. 2, pp. 48-55. El nombre de Lavapies era casi sinécdoque de "majo" en el género entremesil madrileño del XVIII.

54 Huertas VÁsquez: op. cit. (nota 6), p. 129.

55 Ibidem. 
perteneciente a la fiesta le dice a otro “oyes/Pacorro, ¿quiénes son estos?”, y el personaje Pacorro responde "todos somos unos" (pp. 175-75). En Las frioleras, también de Cruz, un "tuno" comenta a un majo, "somos de un oficio/y hemos vivido en un barrio" (p. 159). Dentro de esta comunidad de "álguienes", los majos del teatro popular ejercen su capacidad de reclamar una genealogía dentro del barrio, de trazar un linaje de reconocimiento y conexión vecinal. En la tonadilla La maja constante, de Laserna, una maja del barrio de Maravillas proclama "maja fue mi abuela todita su vida, maja fue mi madre, majas son mis tías, majas mis hermanas, majas mis vecinas, y yo también soy maja de las de crisma" ${ }^{56}$. Los ladrones robados, de Cruz, presenta a un personaje majo afirmando que "majos fueron mis abuelos, /mi padre también fue majo,/y solo ser majo quiero" ${ }^{57}$. El sarcasmo de la maja tabernera en Las frioleras, de Cruz, es palpable: cuando el "Señor" del pueblo, ejerciendo su capacidad justiciera e investigando algunas quejas de la gente del lugar, le pide a la maja las señas de su identidad, la tabernera le responde "lástima es que no traigamos/aquí la genealogía" (p. 160).

Numerosos sainetes presentan la entrada de "la justicia" (alguaciles, escribanos, jueces y otros) en cuadros donde los majos están en calles y lugares públicos. En estas obras, las poblaciones no asentadas representadas por personajes majos reclaman reconocimiento a nivel del barrio y de la calle, invocando la estrategia de "ser alguien" cuando son confrontados por autoridades que pueden arrestarlos. Por ejemplo, en $E l$ mal casado, de Cruz, un majo llamado Tío Lechuzo declara que su "empleo" es ser conocido por otros en el barrio, y una maja llamada Tía Cominos afirma que ella es pariente de mucha gente en las calles vecinas: un soldado, un zapatero, un vendedor en el Rastro, una vendedora callejera de callos ${ }^{58}$. Al final de la obra, cuando un grupo de majos es detenido por las autoridades, un majo declara con valentía "bien sabe too el mundo/quién soy y quién es mi hermana" (p. 390). En Las frioleras, de Cruz, el "Señor" de un pueblo cercano a Madrid habla en la taberna con varios majos, acompañado por el alguacil. Cuando un majo se jacta de su ociosidad y vida inestable, el Señor le pregunta al alguacil “¿Y a éste no le tenéis preso?” (p. 160) -pregunta consecuente dada la realidad de los frecuentes arrestos y reclutamientos para trabajo forzado durante la segunda mitad del siglo XVIII. Pero el alguacil le explica al Señor que él conoce al majo y a sus conocidos en el lugar (p. 160): así, el alguacil revela las funciones entrelazadas de vigilancia y reconocimiento dentro de una comunidad. En el sainete manuscrito Los abusos corregidos, un alcalde de barrio, acompañado por un escribano, entra en un baile para investigar las irregularidades del grupo. Cuando el alcalde pide las señas de identidad a una maja, ella le responde "aquesta noche soy/ doña una de tantas". El alcalde, consciente de la solidaridad de "álguienes" en los barrios bajos, responde "no faltarán parroquianos/a tu reclamo" 59 .

${ }^{56}$ Laserna, Blas de, La maja constante, BHMM, Mss. Mus 100-3, cit. en NúÑEz, Faustino, Guía comentada de música y baile preflamencos (1750-1808), Barcelona, 2008, p. 73.

57 Cruz, Los ladrones robados (1767), en Cotarelo y Mori: op. cit. (nota 1), vol. 1, pp. 380-83, p. 380.

58 CRuz, El mal casado (1767), en Ibidem, vol. 1, pp. 383-90, p. 387.

59 Anónimo [Morales?], Los abusos corregidos, BHMM, Mss. tea 151-19. 
Los barrios periféricos de Madrid y sus calles son los escenarios más frecuentes del teatro popular de la capital en que se presentaba a los majos. Desde el siglo XVII en adelante, la división entre barrios altos y barrios bajos respondía a las olas de inmigrantes en busca de trabajo en la Villa y Corte, de manera que "las clases más desvalidas" se asentaban en las "barriadas... apartadas y humildes" de las afueras de la ciudad ${ }^{60}$. Los bajos son barrios (como lo señala Tovar) de ventas ambulantes, ferias temporales y campamentos, actividades y paisajes efímeros; son espacios a través de los cuales la gente se está moviendo constantemente, de lo suburbano a lo urbano, del sur al norte, de la industria a vender en el centro ${ }^{61}$. Lavapiés, Maravillas, Rastro, y los arrabales constituían una zona suburbial abundante en poblaciones inestables, móviles, pobres, distritos de baja renta donde los inmigrantes y poblaciones pasajeras tendían a refugiarse ${ }^{62}$. Los majos se mueven dentro de estos espacios que "escapan a los reglamentos municipales, a las normas de policía ciudadana, incluso a los controles de la justicia" ${ }^{63}$. Por ejemplo, en Los ladrones robados, de Cruz, un grupo de majos, rumbo a una venta ubicada en las afueras de la ciudad, topan con un gitano y deciden ayudarle en un robo al ventero (p. 381).

Los majos del teatro refieren al espectador a poblaciones que en realidad se movían en "un anillo de tierra casi abandonada pero de vieja historia... donde las viviendas eran el modesto asiento del trapero, del albañil, del zapatero, del tabernero, del calesero, del tratante de hierro, del vendedor de papel y trapo"64. La naturaleza industrial de este espacio fue representada en el mapa de Chalmandrier en 1761, anota Gavira: los distritos de las afueras de la ciudad claramente se muestran como un espacio de equipamientos, instalaciones y fábricas al servicio de la Villa y Corte ${ }^{65}$.

\section{CASTICISMO Y ABYECCIÓN: DOS AUSENCIAS}

“¡Jesús! ¡Qué ruines casillas!” exclama un personaje -en el sainete Las traperas de Madrid, de Ripoll- mientras se abre paso por las calles de los barrios bajos: "¡Jesús! ¡Qué desterradero!/.../¡Jesús! ¡Qué gente tan basta/¡Jesús! ¡Qué olor tan perverso!”66. El "perverso hedor" de los espacios industriales y barrios marginados refiere a los espectadores tanto a lo que se conoce sobre el margen y la periferia de la Villa y Corte, como a lo que es abyecto, en el sentido definido por Kristeva: lo abyecto es aquello que está "radicalmente excluido... Está afuera, fuera del conjunto cuyas reglas del juego parece no reconocer" ${ }^{67}$. Lo abyecto de "la españolidad" en el Madrid del siglo

\footnotetext{
${ }^{60}$ Mesonero Romanos: op. cit. (nota 20), p. 191.

${ }^{61}$ Tovar Martín, Virginia, «Madrid: Sugerencias sobre lo urbano y lo arquitectónico en el teatro de don Ramón de la Cruz», Anales de Historia del Arte, 9 (1999), pp. 219-236.

${ }^{62}$ López García: op. cit. (nota 6), p. 43.

${ }_{63}$ Tovar Martín, Virginia, «El majismo y las artes plásticas», en Huerta Calvo: op. cit. (nota 6), pp. 97-115.

${ }^{64}$ Tovar Martín: op. cit. (nota 61), p. 227.

${ }^{65}$ Gavira Golpe, Carmen, «La ciudad y la no ciudad. Madrid (1567-1993)», en Gavira Martín, José y Gavira Golpe, Carmen (eds.), Madrid: centro y periferia, Madrid, 1999, pp. 111-48, p. 117. Para más sobre estos espacios de la industria, ver: Ruiz, Rafael, Nieto Sánchez, José M., y otros, Historia del barrio de Embajadores, Madrid, 2008.

${ }_{66}$ Ripoll, Domingo, Las traperas de Madrid, BNM, Mss. 15279.

67 KRISTEVA: op. cit. (nota 13), p. 11.
} 
XVIII es una herida abierta por las luchas de la ciudad en torno a inestabilidad vivida por la mayoría de la población urbana, condición -i.e., la inestabilidad- no captada por categorías conceptuales como "extranjero", "forastero", o "vecino". Como lo señala Kristeva, "No es la falta de limpieza o salud lo que causa la abyección, sino lo que perturba la identidad, el sistema, el orden. Lo que no respeta los límites, los lugares" (p. 13). No son "las ruines casillas" ni "el olor perverso" lo que acondiciona la abyección del ámbito del majismo madrileño dieciochesco, sino el hueco creado por su exclusión de definiciones y prácticas oficiales referentes a "lo español", y de la categoría cultural de "lo castizo".

"No existe idea social que no sea a la vez una recuperación de los recuerdos de la sociedad" afirma Halbwachs ${ }^{68}$. La "idea social" de lo castizo se desarrolla como un espacio de memoria colectiva que responde a las necesidades grupales de la gente -los madrileños luchando por décadas para afirmar sus reclamos de españolidadconstantemente sometida a la inestabilidad. Los sainetes y las tonadillas que tratan las prácticas y lugares del majismo nos refieren a "la presencia de diversas ausencias", como lo advierte De Certeau: "Los objetos y las palabras también tienen lugares huecos en los cuales dormita el pasado, como en los actos cotidianos de caminar, comer, irse a la cama, en los cuales sueñan las antiguas revoluciones" ${ }^{69}$. En las páginas que siguen trataré dos ejemplos de estas "ausencias que duermen" dentro de la ubicación del majismo castizo. La primera es la de los arrestos y el reclutamiento para trabajo forzado entre los habitantes de la periferia y los barrios bajos; y la segunda, el "lugar hueco" implícito en la iconografía de los majos bailantes.

Mientras (señala Morán) la ciudad es "inseparable del movimiento de sus habitantes, caracterizándose por la fluidez que producen los inevitables desplazamientos de sus moradores" (p. 18), la exclusión social y el desplazamiento forzado de los pobres, ya marginados, era una realidad en expansión en el siglo XVIII. Uno de los factores citados en 1782 para justificar la creación de la Superintendencia General de Policía fue el crecimiento demográfico en las áreas urbanas, debido en parte al incremento en la inmigración a centros como $\mathrm{Madrid}^{70}$. El reformismo borbónico acrecentó esfuerzos para eliminar a las poblaciones de pobres, marginales, y delincuentes de las calles urbanas y las condenó a casas de trabajo y colonias penales ${ }^{71}$. Desde 1745 , la categoría de "vagancia" se expandió para incluir a "aquellos sin trabajos (ociosos), [aquellos] quienes gastaban el día en tabernas (malentretenidos), quienes no querían aprender un oficio (inaplicados)... [o] no tenían un lugar para vivir"72. En otras palabras, las mismas poblaciones en riesgo e irregulares que Fumerton caracteriza como

\footnotetext{
${ }^{68}$ Halbwachs, Maurice, On collective memory, trad. Lewis A. Coser, Chicago-Londres, 1992.

${ }^{69}$ Certeau, Michel de, The Practice of Everyday Life, trans. Steven Rendall, Berkeley, 1988.

70 Requena Hidalgo, Jesús, «Inmigración, ciudad y policía», Scripta Nova: Revista electrónica de Geografia y Ciencias Sociales, 94 (Agosto 2001), p. 2. Ver también López GARcía: op. cit. (nota 5).

${ }^{71}$ PIKE: op. cit. (nota 42), p. 50. En este contexto, ver también Alloza ApARICIO, Ángel, La vara quebrada de la justicia: un estudio histórico sobre la delicuencia madrileña entre los siglos XVI y XVIII, Madrid, 2000; DOMíNGUEZ Ortiz, «La Galera o cárcel de mujeres de Madrid a comienzos del siglo XVIII», Anales del Instituto de Estudios Madrileños, IX (1973), pp. 277-85; López Barahona: op. cit. (nota 42) y Pérez Estévez: op. cit. (nota 31).

${ }_{72}$ Alloza Aparicio, Ángel, López García, José Miguel, y otros, «Prevention and Repression: Food Supply and the Public Order in Early Modern Madrid»: www.historiasocial.org/wp-content/uploads/2010/01/prevention-andrepression.pdf; sin paginación.
} 
“inestables". Entre 1766 y 1768, en los dos años inmediatamente posteriores al Motín de Esquilache, 5.790 personas, o sea el 3\% de la población de Madrid fue detenida y acusada de vagancia ${ }^{73}$. Aquellos que eran arrestados eran enviados al servicio militar, a casas de trabajo o reclutados a la fuerza para trabajo duro en obras públicas y carreteras, o en las fortalezas e instalaciones africanas y peninsulares. Entre 1668 y 1780, más de 9000 delincuentes fueron condenados a galeras, fuertes y a las minas reales en Almadén ${ }^{74}$. Sánz Sampelayo comenta sobre la importancia de los presidios de África del norte en relación con las migraciones internas: entre 1730 y 1787 , el reclutamiento para trabajo forzado había convertido a los puertos sureños de Andalucía en un "puente humano y centro de reexpedición en la labor de abastecimiento"75.

En numerosos sainetes, los personajes majos hacen referencia a sus experiencias con arrestos, labores forzadas y presidios. El ejemplo más famoso puede ser el de Manolo, el protagonista del sainete epónimamente titulado, escrito por Cruz: Manolo ha sido enviado a los presidios en África diez veces, mientras que sus amigos y parientes en los barrios bajos han sido enviados a casas de trabajo ${ }^{76}$. Al final de $\mathrm{El} \mathrm{mal}$ casado, de Cruz, el majo Ciprián se burla de las autoridades que lo están arrestando, diciendo que "diez años de presillo/en un instante se pasan" ${ }^{7}$. De acuerdo a los majos de El muñuelo, de Cruz, Lavapiés ha sido siempre "el non pus de azotados y azotadas", un barrio donde es tan probable que a los majos se les sentencie a la horca como que se les envíe a labores forzadas en las minas ${ }^{78}$. En el sainete manuscrito $L a$ expulsión de las majas de Madrid, Catuja, una maja, y Manolo, un majo, se encuentran en Carabanchel (un pueblo de la clase trabajadora en las afueras de la capital) y discuten las dificultades de sobrevivir en los barrios bajos, dada la constante amenaza de encarcelamiento y las actividades de vigilancia de las autoridades ${ }^{79}$. A Catuja, Manolo le cuenta que él ha escapado hace poco de prisión, y una maja entre su círculo de amigos fuera puesta en la Galera. Manolo le informa a Catuja que las autoridades la están buscando a ella también, y relata la historia de otra conocida suya del barrio las Maravillas, la cual fue detenida por las autoridades y puesta en San Fernando "por alcahuetona" (por manejar una red de prostitución); su esposo, en la vergüenza fue exhibido en una mula por las calles públicas. En el cierre de la obra, Manolo y Catuja acuerdan escapar al vecino arrabal de Vallecas (un asentamiento de la clase trabajadora), y le piden al auditorio que rece por sus almas "si acaso vienen a ahorcarnos".

Otra "ausencia" o aporía conllevada por el supuesto casticismo del "españolísimo gremio" se localiza en la conexión entre los majos, el baile y los "alborotos". En docenas de sainetes, los majos son representados bailando en parejas o en festivos grupos. Las seguidillas bailadas, que eran uno de los elementos centrales de tonadi-

\footnotetext{
${ }^{73}$ López García: op. cit. (nota 5), p. 99.

${ }^{74}$ Alloza Aparicio: op. cit. (nota 72).

75 SAnz Sampelayo, Juan, «Andalucía en el contexto migratorio de España en la edad moderna», en VILLAR GARCÍA: op. cit. (nota 3), vol. 1, pp. 101-120.

${ }^{76}$ Cruz, Manolo, p. 50.

${ }_{77}$ Cruz, El mal casado, p. 39.

${ }^{78}$ Cruz, El muñuelo, en Bauer, Ignacio (ed.), Sainetes, Madrid, s.f., pp. 33-60, p. 49.

${ }^{79}$ Carabanchel era un pueblo que durante el período estuvo asociado (entre otros productos industriales) a la fabricación de jabón que cubría las necesidades de lavado de la ciudad.
} 
llas y sainetes, se integraban con frecuencia como componente básico del majismo teatralizado ${ }^{80}$. El espectáculo teatral del majo que baila transmutó, a principios del siglo XIX, en las culturas de boleros, fandangos, y flamenco, para los cuales el baile constituye un componente fundacional ${ }^{81}$. El baile de los majos dieciochescos se representa en espacios abiertos, tales como calles, plazas, casas públicas (tabernas, ventas) y fiestas. Tal escenificación de majos bailantes es una ubicación para el topos del comportamiento exaltado y escandaloso que caracterizara al majismo, desde los sainetes Las frioleras (cuya acción comienza con unas majas bailando en una taberna) y El deseo de seguidillas (en el que un personaje expresa el deseo de "oír/a una muchacha de trueno/cantar unas seguidillas/.../y...bailar con toda el alma/y todo el cuerpo" [p. 117]), ambos de Ramón de la Cruz, hasta la crítica a los majos, hecha por Wenceslao Ayguals de Izco a mediados del siglo XIX en su novela María, la hija de un jornalero, en la cual éstos aparecían como un "populacho" y "la gente de trueno" del "célebre barrio de Maravillas" 2 .

Pero los textos del teatro popular transmiten igual cantidad de referencias a la conexión entre majos y los alborotos de barrio. El baile de los majos iba de la mano de su propensión a alborotar. El Diccionario de Autoridades define "alborotar" como "alterar, inquietar, turbar la paz... turbando el orden de las cosas, o con voces, o con hechos y pendencias". Grases ha rastreado la red semántica que explica el término "alborotar", y anota que "alboroto" tiene connotaciones tanto de "muchedumbre en desorden" como de performance: "la evolución ha sido de "baile' a 'alboroto""83. Palabras como "zambra" se ligan con "alboroto" y "baile" dentro de este espectro semántico. Por ejemplo, en El careo de los majos, de Cruz, un personaje (comentando el comportamiento de los majos de Lavapiés) observa "vea usted, con tal gentuza,/iqué tal sería la zambra!" (p. 281); al final de la obra, el alcalde decide dejar libres a las majas, con tal que no alboroten: "apercibidas/ellas de que no armen zambras/ni juntas escandalosas" (p. 283). En Las majas vengativas, también de Cruz, un alguacil manda a los majos a que "ajusten" la disputa que ocasionó un alboroto reciente, ya que "ajustada/la discordia, ha de ser todo/meriendas, bailes y zambra" (p. 459).

Los sainetes de Ramón de la Cruz presentan constantemente a majos deseosos de bailar y dispuestos a alborotar, y en estos textos, "alboroto" se aplica a una amplia gama de comportamientos y/o disturbios dentro de espacios como casas, calles y barrios. En El careo de los majos, una maja "tiene alborotada toda la vecindad" con su inclinación al chismeo, la mala leche, y la venganza (p. 282); en Manolo, los albo-

80 Sobre este componente del género entremesil, ver: Lolo, Begoña, «Itinerarios musicales en la tonadilla escénica», en Lolo, B., Labrador, Germán, y otros (eds.), Paisajes sonoros en el Madrid del S. XVIII: la tonadilla escénica, Madrid, 2003, pp. 15-30; y PrESAS, Adela, «Aproximación a la forma literario-musical de las seguidillas en la tonadilla escénica», en Álvarez Barrientos, Joaquín y Lolo, Begoña (eds.), Teatro y música en España: los géneros breves en la segunda mitad del siglo XVIII, Madrid, 2008, pp. 149-64.

81 Ver, en esta conexión: SuÁrez-PÁJares, Javier y CARreira, Xoán M., The Origins of the Bolero School, trad. Elizabeth Coonrad Martinez, Pennington, NJ, 1993; Blas Vega, José, Los cafés cantantes de Madrid (1846-1936), Madrid, 2006; NúÑEz: op. cit. (nota 5); y Romero ToBAR, Leonardo, «Teatralidad y andalucismo en el Madrid de mediados del siglo XIX: El género andaluz», Costumbrismo Andaluz, en Álvarez Barrientos, Joaquín y Romero FERrER, Alberto (eds.), Sevilla, 1998, pp. 149-168.

82 Ayguals De Izco, Wenceslao, Maria, la hija de un jornalero, Madrid, 1846-47, 2 vols., cap. XIII, p. 116.

${ }^{83}$ Grases, Pedro, «La idea de 'alboroto' en castellano», Thesaurus, VI.3 (1950), pp. 384-430, p. 395. 
rotos de los majos tienen que ver con el juego, el hurto, y el maldecir (p. 49). Cuando un majo no cumple con una promesa de matrimonio en Las majas vengativas, una maja "alborota" el barrio, y los vecinos llaman a la justicia (p. 459). En La crítica, un alboroto entre vecinos atrae a la justicia, y el escribano viene a ser el blanco de la ira de los majos de la calle, que "alborotan" y se lanzan en contra de él (p. 389). Cuando el juez intenta averiguar los pormenores de los alborotos, una maja le comenta que "pasan/los que hay de diez cada día" (p. 390). Al final de El mal casado, un grupo de majos vecinos son tomados presos por la justicia, que ha acudido a investigar un alboroto entre ellos. Aún cuando se tuviera en cuenta la convencionalidad de la disposición alborotadora del majo teatral, es un hecho innegable que las obras del género entremesil reflejan una realidad social de la época: el hecho de que "los alborotos" entre los miembros del pueblo eran investigados y castigados con dureza. Las autoridades arrestaron o reclutaron a la fuerza a una serie de personas "alborotadas", desde hombres que golpeaban a sus esposas hasta niños desobedientes o vecinos que causaban "alborotos" o molestias ${ }^{84}$.

Al majo que quisiera alborotar, Madrid ofrece abundantes oportunidades, según un personaje en Manolo, de Cruz: después de todo, "¿en qué país/hay tantas civiles guerras/como aquí, que hay pretensiones,/primos, cuñados y suegras?" (p. 48). Pero el origen de los alborotos entre majos teatrales, es el mismo entre los actuales residentes de cualquier ciudad grande: resentimientos entre parientes, sospechas entre vecinos, el sinfín de "civiles guerras". Las obras del género entremesil madrileño imaginan a barrios a través de cuyas calles y espacios públicos resuenan ecos de actuales "desórdenes" traídos a la Villa y Corte por inmigrantes, transeúntes y trabajadores que despliegan estrategias de solidaridad en barrios bajos tales como Lavapiés y Maravillas. Y estos barrios bajos, que se conceptualizan por Mesonero como "valladar impenetrable a las personas decentes", llegan a ser "escenario exclusivo del casticismo", en palabras de Tovar ${ }^{85}$. La mayor parte de los ambientes naturales y construidos del majismo dieciochesco han sido derribados, construidos de nuevo o alterados; así que contamos con poca evidencia material sobre el paisaje dentro del cual las poblaciones representadas por los majos teatrales se movían y reclamaban su españolidad. El casticismo evoca una constelación de sitios de memoria en torno a la inestabilidad (unsettledness), cuyo paisaje urbano correspondiente, el cual está en los barrios bajos, ha cambiado durante mucho tiempo y ha sido quitado de vista. Lo abyecto inherente al casticismo se erige precisamente en las formas desmemorizadas de los espacios periféricos, en el escenario de lo que se calificaba como "indecente", "impenetrable", o de ninguna consideración. La españolidad de los majos apunta a una parte esencial de la identidad castiza: ser posicionado con respecto a un pasado que quizás sea jamás recuperable, y cuyos nombres han sido transformados por el desplazamiento, la integración, la adaptación. Por lo tanto, la representación teatral de los majos sugiere que en el Madrid del siglo XVIII, la constitución práctica de la "españolidad" fuera dependiente de la inestabilidad fundamental de los muchos "álguienes" que simplemente trataban de sobrevivir. De ahí que el majo representa no

${ }^{84}$ PIKE: op. cit. (nota 42), pp. 51-52.

${ }^{85}$ Mesonero Romanos: op. cit. (nota 20), p. 196; Tovar Martín: op. cit. (nota 61), p. 235. 
tanto la bravura y la fiereza, la resistencia -características siempre asociadas con el tipo "majo/a" en la literatura popular- como una convergencia de realidades sociales, judiciales, espaciales y económicas: la realidad de la vigilancia de las autoridades; la realidad de leyes que potenciaban la conversión de poblaciones inestables a reclutados por fuerza y encarcelados; la realidad de los barrios testados urbanos y los muchos conflictos entre vecinos viviendo en condiciones de hambre, pobreza e incertidumbre. Y la realidad del baile como práctica social entre vecinos en un barrio, o en una calle. El fogoso baile del "gremio españolísimo" del teatro popular dieciochesco captura tanto una presencia como una ausencia: la presencia de negociaciones en torno a la memoria colectiva (implícita en el casticismo), y la ausencia de marcadores, dentro del repertorio tipológico del "majo que baila", referentes a la lucha social inherente al proyecto de la ciudad capital. 